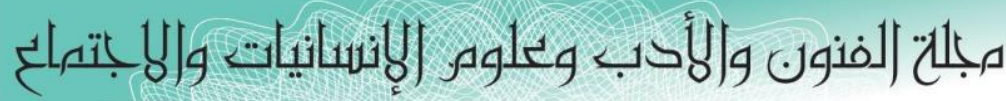

Journal of Arts, Literature, Humanities and Social Sciences

ISSN online: 2414 - 3383

ISSN print: 2616 - 3810

العدد (39) حزيران - يونيو 2019

LALLHSS

num.jallass som

\title{
Comparative Study of the Function of Goddesses in Mesopotamian Civilizations, Elam, Iran, India, Greece and Egypt
}

\author{
Asst. Lecturer: Arazoo Rasool Ahmed \\ Department of Education - Faculty of Education and Languages \\ Lebanese French University \\ Erbil - Iraq \\ arazoorasool@lfu.edu.krd
}

\begin{abstract}
In various myths of history, such as Mesopotamia, Egypt, Greece, and ancient Iran, goddesses entered the sacraments of the people, which have been named in some of the ancient texts. So that, in Mesopotamian mythology and in one of the ancient Sumerian texts, the goddess "Ishtar" or " Sumerian Inanna" is mentioned parallel to Anahita of Iran, as the goddess of war and love, which represents the political and social value of women in that Mesopotamian community of that time. In the myths of Greece, Egypt and ancient India there was also a belief in the rearing and fertility of the woman. On the other hand, some other goddesses who were the messenger of spring, blooming, love, purity of the earth and heaven, were worshiped, and some statues of them are also remained. It should be mentioned that the goddesses in various ancient societies had different functions, depending on the geographical location and the time and place in which they were located, their purity and worship was changed. Since there were political, economic, cultural, and religious relations in those days, it was natural for the goddesses of the associated territories to have different forms, and it was even possible to be worshiped and to allocate certain places for worship in those territories, which is applicable to Mesopotamia and Elam. In this research process, it is tried to use the descriptive, analytical and comparative studies to explore the goddesses in Elam, Mesopotamian, Iranian, Indian, Greek and Egyptian civilizations. It is inferred from this text that there were similar goddesses with the same functions that were worshiped by the people, and they were called when needed.
\end{abstract}

DOI: $10.33193 / J A L H S S .39 .32$ 


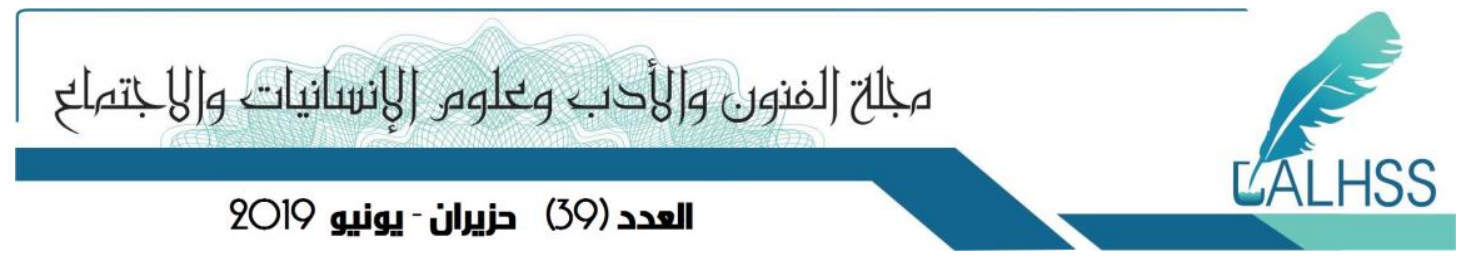

\section{Introduction}

Humanity has benefited a variety of religious ideas in its long history. Worship of the mother-gods is one of these types. The abundant statues found through excavations carried out in different regions confirm the existence of the tradition of worship of the mother-gods and goddesses, the oldest religious tradition, in the old world.

In all societies, there has been a division of labor between women and men throughout history. Based on historical information and evidence obtained in communities, hunting and gathering foods were the most important activities of this community, and the division of labor was based on gender and age. Hunting, warfare, political and religious, ceremonial and artistic activities were the responsibility of men, and collecting and supplying herbal food and childcare were the responsibility of women. The responsibility of women for the preparation of food, reproduction and maintenance of children creates this meaning for the human community at a time that the female is a guarantee of the survival and life of the human community. Based on this conception and image of women, they gained more power in society and in a society where natural hazards continually threatened the human society, the persistence of life by women turned into a sacred matter, and women, the conquerors of this continuity of life, were sanctified to the extent that they were praised as goddesses and mother-gods. Believing in these sanctities and the fertility and dynamism of women in different lands, they have been called goddesses, for example the goddess of water, which is a female god and is also mentioned in myths. In addition, and based on historical and archaeological evidence, some scholars believe that speaking and inventing vocabulary for the transmission of abstract concepts was founded by women, as women needed to talk with children and to communicate with other tribal members. That is why, in all cultures and languages, the language of the conversation is called mother tongue. In sum, and because women in the ancient age had the main task of life, they were worshiped as a goddess for their dignity and respect. Perhaps the most important cause was the fertility and reproduction that caused the woman to be sacred in this age, and even to be worshiped as a goddess. The goddesses of fertility, water, justice, love, beauty, etc. are only examples of women goddesses, each existed in Mesopotamian civilizations, Elam, Iran, Greece, India and Egypt, with different names and with almost identical functions that guaranteed the life of human societies in conditions which the early humans were constantly faced with natural devastating threats.

\section{The purpose of the research}

Considering the position of these goddesses in the above mentioned civilizations, this study attempts to "study the functions of similar goddesses in Mesopotamian, Elam, India and Egypt". In this study, we will also examine the functional differences and similarities of these goddesses in these societies. 


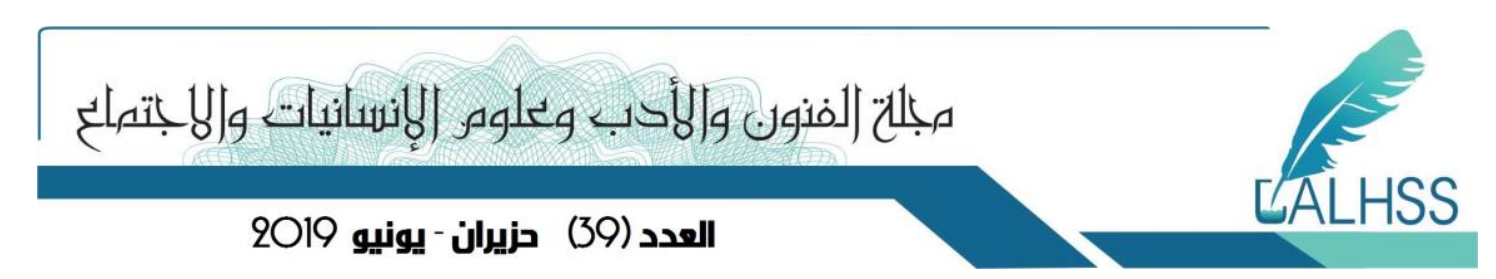

\section{Research questions}

Accordingly, the main questions of the research will be:

- What are the common goddesses of Mesopotamian civilizations, Elam, Iran, India and Egypt?

- What was the function of each of these goddesses in each of the mentioned civilizations?

- Did the same goddesses have the same functions in different civilizations?

- What are the differences and similarities between the similar goddesses in the studied civilizations?

\section{Research method}

The method used in this research was a qualitative comparative study that was based on comparing the functional indicators of the goddesses among the mentioned civilizations.

\section{Goddesses of Elam, Mesopotamia and Iran}

Archaeological discoveries have shown throughout Western Asia, Iran and Central Asia, Egypt and Greece in the west to the Sindh valley and the Hindu Kush Mountains in the east, the mother-god was worshiped from the ancient times. The document of believing in mother-god can be found in the existence of many abundant statues, often without head, and sometimes giving birth to a child. Sometimes it has a child in the arm. This goddess is the symbol of fertility, blessing, and the divine symbol of childbirth and motherhood (Bahar, 2007: 393). In fact, with the invention of agriculture by women and the domestication of wildlife, humankind has taken a step toward mastering its environment, and so the importance of women has become much more significant. In the Neolithic era, unlike the Paleolithic era, the great goddess which dominated on all affairs and phenomena, changed into diverse goddesses for various affairs that had a prominent personality and directly involved in the daily life of the people, and she was also symbolically linked to the moon, water, rain, and the fertility of women and the growth of plants (Eliade, 1997: 162-163). The women's statues of the Paleolithic and Neolithic period, some of them thirty thousand years old, reflect the dominant position of women before patriarchal authority in ancient societies. Archaeology across the Western Asia, Iran and Central Asia from Egypt and Greece in the west to the Sind Valley and the Hindu Kush mountains in the east have introduced us to the very ancient and grand praise of the mother-god in prehistoric times. The reality of the belief in mother-god can be found in the numerous statues of a goddess considered a symbol of fertility, blessing and endowment. She was the supporter and cultivator of the heavenly Son, and was the divine symbol of the childbearing of women and motherhood (Bahar, 2002: 393). In Iran, for the first time, it was based on the excavations of Shush that the worship of the goddesses was discovered. In west of Iran, in the Sarab hill, a woman's statue was discovered that dated back to $6000 \mathrm{BC}$, and indicated the existence of the mother-god in Iran (Eskandari, 2001: 133). Of course, the tradition of worshiping mother-gods has been observed in different parts of the world, such as Iran, Egypt, Greece and the Mediterranean coast (Gaviri, 2000: 14). 


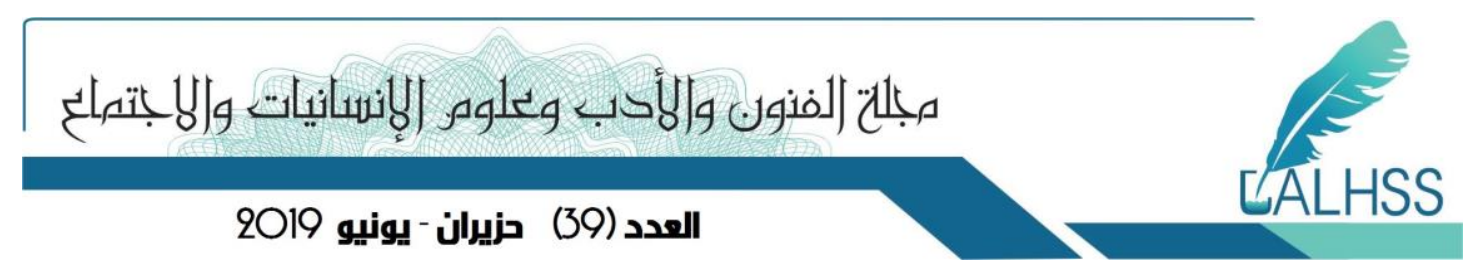

The role of the goddesses in the collection of Elam gods is more significant than elsewhere. The list of the forty gods mentioned in the Naramsin treaty was begun with Pinenkir, the goddess of love and fertility, which was worshiped throughout Elam and had an Ashtam or fertility house; she has been featured repeatedly in artwork. The collection of Elam gods was originally consisted of the gods of the political units of Elam; it is not surprising, then, that different gods have had the same roles and similar cases have been attributed to them. So that, several of them was called "Great Goddesses", which means the superior god. Elam's references are not so informative about the character of the gods, but Mesopotamia texts are used to fill this gap, although they are in most cases late references. In the Akkadian texts it can be seen that Lagamal (worshiped throughout the Neo-Elamite period 1000-539BCE) is the same as Nergal (god of underworld), and Napirisha (with a snake figure that symbolizes primordial waters) is the same as Ea (Mesopotamian god, who rules the primordial waters of the abyss). Lagmal is the Infernal God, and Napirisha, with his bed made of a snake with a human head, can be distinguished in Kurangun relief (Giovinazzo: 329). Originally, the dominant figure seems to be the great goddess Pinenkir. That is, the first name to be called in the Naramsin Treaty, while Inshushinak is placed on the second rank of the gods. This conquest and prominence of a high goddess is probably the reflection of the way of the materialistic life that has been more or less characteristic of Elam civilization at all times, even when the superiority of a male god in this collection of gods is fully recognized, probably influenced by Western beliefs. In a way that the ritual ceremonies of the goddesses have always maintained their popularity in all parts of the empire. Some compare this goddess to the goddess Ishtar, the Mesopotamian goddess (Sarraf, 2005: 34).

In Elam, the Pantheon goddesses'/ gods' congregation (the place of gods) are consisted of goddesses such as Baba and Mam, or the wives of gods without special attributes such as Serpenito and Tethimeto (probably foreign and Akkadian), or in Mesopotamia it is consisted of the gods related to death and the underworld, such as Ereshkigal, An or Gaval. Gaval, known as the Great Lady physician, is originally the Goddess of Death, as its animalistic symbol in the form of a dog shows (Majidzadeh, 2000: 182).

Another goddess in Elam, which had a homologous in Mesopotamia, was Manzat. This goddess was worshiped in Mesopotamia by the name of Ninali. It seems that Ninali was one of the oldest Babylonian gods who formed a couple with Babylonian Adad in Mesopotamia, which means "the city" in Akkadian (Sarraf, 2005: 36). On the other hand, the goddess Manzat in Mesopotamia was likened to Ishtar by the scribes of Akkadian (Eduards, 2012: 60). In the Elam of that day, the god Biltia, means "my lady" can be adapted with Babylonian Ishtar; because one of the successors of Untash-Napirisha, the king of Il Elam, described the goddess as Tantar, the Lady of Babylon (ibid, 64- 65). From these indications and references in Elam religion, it appears that their beliefs contained the views and beliefs that prevalent in most of the early Middle Eastern religions, with the obvious effect of the rituals of Mesopotamia (Edwards, 2012: 73) and is in some way in harmony with their gods and goddesses.

In the 4th millennium BC, in Mesopotamia, they believed that life was generated by a goddess. The world, in their view, was pregnant, not born, the source of life was female, and 


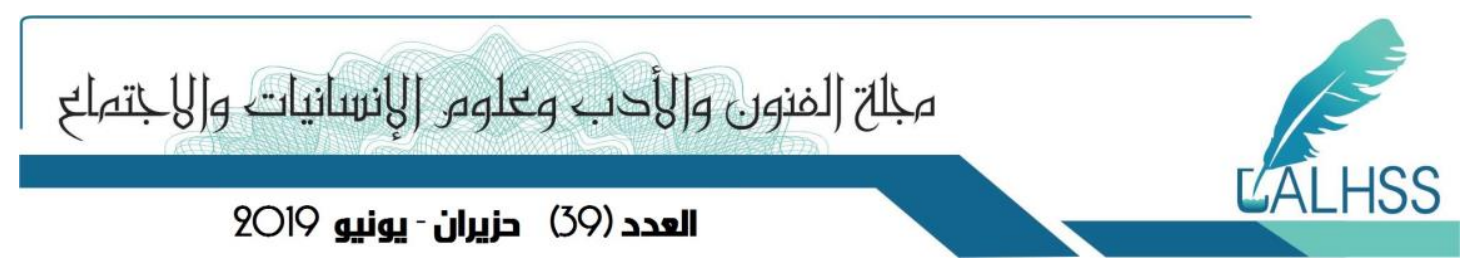

for that and because of the appearance of small statues of naked goddesses on the Iranian plateau, one can assume that Iranians have had such an attitude toward life. (Esmailpour, 2008: 76). At the beginning of the urbanization period in Mesopotamia, we find temples that are in pairs, and they are likely to indicate that there is a belief in a heavenly husband and wife. In all historical periods, the great god of Uruk, in Mesopotamia, was the goddess Inna, sometimes called Inanna, which meant the Lady of the Sky in Sumeria (Bahar, 2005: 29). The goddess Inanna had a husband named Dumuzi. Believing in the marriage of this gracious blessing god with Inanna at the onset of the spring and his next martyrdom in the same year that was the epitome of the life and death of the unstable world, and the annual celebration of this ritual in the beginning, and the rituals of the remarriage of the goddesses in this time was at the center of Mesopotamian beliefs (Warner, 2007: 41). People mourned in the martyrdom of this god, and were happy because of the goddess's remarriage. In other words, the death of Dumuzi was the symbol of the death of the unstable world (Getty, 1990: 17) and the re-marriage of the goddess caused the re-growth of plants and fertility of trees and animals; and it was believed that by displaying the ritual of the death of the god and the remarriage of the goddess, it would be possible to prevent the stopping of the yearly seasonal movement and confirm the repetition of plant and animal life, which has a magical base. Nowruz, at the beginning of the spring reminds this old native tradition in Mesopotamia (Bahar, 2005: 29).

It should be mentioned that during the initial periods, the inhabitants of each city and village worshiped the native god which many of them were fertility goddesses that ensured the welfare of the community, while the most important members of the pantheon (Assembly of the Gods) were at the head of the major cultural and political centers, the gods like Nana-Sin, goddess of the Moon in Ur, Utu the god of Sun in the city Larsa, Ninhursag, the mother-goddess in Kish and Nin Isina, the Healing goddess in Isina (Iles Johnston, 2015: 224). Ninhursag is in fact the ancient Sumerian goddess, which was entered to the groups of gods in Elam and worshiped due to the political-religious influence of the country (Cameron, 1936: 125). The moon, which appeared as a crescent, was one of the Elams goddesses, apparently entered from Mesopotamia to Elams, where was called Sin (Hinz, 2010: 58). This God in Elams was the father of orphans. The crescent of the moon represented the god Napir in Elams. The name of the god Napir in the Hitta treaty appears in two places along with three goddesses, which, of course, have been sworn in by the group of witnesses. The goddess in Sumer was consistent with Nana. In fact, it must be mentioned that the moon in the universal symbols was a symbol of the mother-goddess and the power of femininity, queen and paradise (Cooper, 1968: 107). Thus, the imagination of fertility of animals and productivity of plants by the moon led to the belief in the Moon God as the fertility goddess that was seen in most pre-Aryan civilizations in Iran called the mother-Sin and Nana (Pourdavoud, 1977: 23).

The bronze decorative object dated back to 1000BCE which was found in Lorestan (province of Ilam) depicts the role of this goddess which clarifies the connection of feminism and the moon. Professor Ackerman, an American historian of artworks of Iran, 


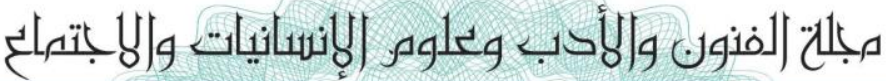

\section{العدد (39) حزيران - يونيو 2019}

believes that this role is among the first signs of the connection between the fertility goddess and the Moon goddess (Samadi, 1988: 23).

Ninatud, or Ishtar, the Venus God, the worshiped god in Kish, was one of the most important goddess in Mesopotamia, and the worship of its peers can be seen in most of the civilizations and territories of that day of the ancient world. In Mesopotamia, the goddess of Ishtar had a great reputation and was most highly praised; she was the goddess who was both goddess of war and goddess of love and lust. This goddess is almost the same as the Anahita or Venus who was praised by the Persians (Aria, 2003: 34). This goddess appears in Mesopotamian mythology as well as in correspondence from the West from Anatolia to Egypt, under the same name or alien names in all roles. In Mesopotamia, she was the city of Uruk, where she was initially referred to as a girl and later as the wife of Anu, the god of the heavens and the god of gods (Majidzadeh, $2000: 182$ ). The image of this goddess is presented in the carvings of Annubanini, the king of Lullubi, the king standing in front of her. The text of this epitaph is in praise of Ishtar and other goddesses of the Akkadian era. About this goddess, some believe her rituals continued as Nanai to the Parthian era, and the numerous ceramic statues found in the party cemetery indicate that the name still remains for Iranian mothers ( Hejazi, 1991: 34). According to Herodotus, the Iranians had learned to sacrifice for this heavenly goddess. Herodotus knows the position of Anahita(Figure1) among the Persians similar to the goddess Anat of the tribes of Syria, Ishtar of Babylon, Kumanai of Hittites, and Aphrodite of Greece (Faniyan, 1972: 234). Although the royal family was honest in their tendency to the Zoroastrian religion, they also clung to the worship of this foreign goddess. The western Iranians praised Ishtar by the name of Anahitish (pure), a name that they had given to the Venus planet, then, using the Avestan adjective Anahita (pure), this Anahitish was transformed into the goddess Harhuti Ardvi Sura (Boyce, 2002: 89).

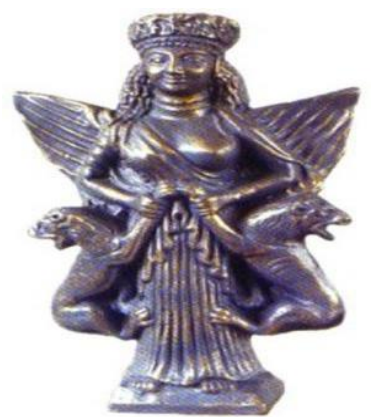

Figure1. The image of Anahita/ Ardvi sura Anahita

(Pashtunizadeh, 2017:98)

Similarities of the Anahita in Ancient Greece, Iran, India, and Egypt 


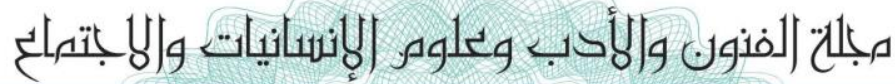

\section{العدد (39) ريران - يونيو 2019}

In ancient Elam, a goddess been mentioned as Shazi, who is the goddess of the rivers and she was asked for help in trial as the judge of hard-judgments (Hinz, 1997: 57). It can be compared to Anahita somehow. According to Justi, this goddess was also of interest in neighboring countries, and she had taken some traits of goddesses of foreign nations amongst the Sami people of Iraq and in Asia Minor (Yashts, 1968, v. 1: 164).

This worship of the goddess Anahita / Anahid was gradually drawn to the west, to Anatolia and Greece, perhaps through Cyprus and Crete. In particular, the most popular image of Venus, the Greeks' Aphrodite (Figure 2), shows her as coming from the sea on the coast of Cyprus, while Adonis, one of the Sami Gods is accompanying her. The ritual of this goddess with a purely Greek face with Aphrodite was well-deserved. This ritual was expanded throughout the Persian Empire / Achaemenid Empire and in various ways merged with the rituals of Athena, Aphrodite and Sibel in Anatolia (Warner, 2007: 41-42). In Greece, most of the early gods were first goddesses, and in this case it would be natural to know her as a wife of the new god, and if he was a god, they might have introduced him as a son of the new god, but this would require a mother, that is, a local goddess or fairy. This was a very natural and simple childish thing, but since this is the case in many of the various valleys and islands that the Greeks live in, and because these local and ruling gods are more and more were unified with Zeus and Apollon, gradually it seems that Zeus and the Apollon have been merged (Kitto, D., 2014: 240). Greek writers considered this goddess as the Aphrodite Anaise or simply Anaise. According to the Greeks, the goddess was born from the water foam of the sea, with a clear skin and elegant body, slightly farceur and coquets, but far away from the behavior of prostitutes in temples, but self-control (Noss, 1994: pp 142-143).

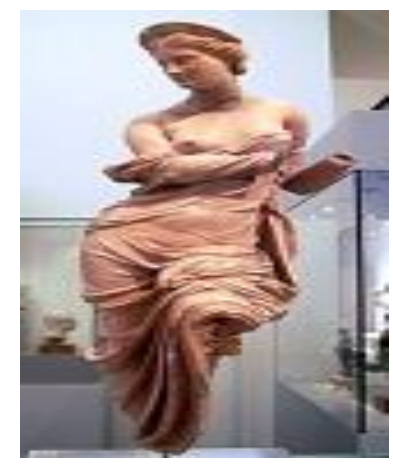

Figure 2. The image of the goddess Aphrodite, the goddess of love and beauty in ancient Greece

(Taheri, 2007:52)

It should be noted that Anahita was the source of all fertility in the beliefs of the Iranian people of ancient times and cleanses all the sperm of men and cleansed the wombs of all the mothers (Hinnells, 1994: 39). She is known as the peer of Sarasvati in the Vedic religion, and others believe that the Ardvi was originally an adjective for Sarasvati, that was used to name a small holy river in the present Punjab region, in India, but in Iran, it was turned to 


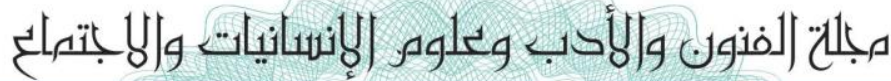

\section{العدد (39) حزيران - يونيو 2019}

Harakhvati (Amouzegar, 2007: 23). Sarasvati is called the presentation of speech in postVedic myths in India, and in Atharvaveda, each of the gods is requested according to their characteristics, Sarasvati, who is the representation of spirituality, is requested for the speech (Gaviri, 1993: 33). This is the same goddess who is the tantamount of Maraspand, the Iranian goddess, and the symbol of the word and the speech of Avesta (Christensen, 1953: 478). According to Logemel, her Iranian name was Harahvati, which is described in Avestan texts with the names Sura-Aredvi and Anahita. From his point of view, these two goddesses are in fact two different displays of an ancient Indo-Iranian goddess who represents the heavenly river, the god who floods the waters in the rivers (Malandra 1983: 119). On the other hand, Aphrodite was equal to Hasour (Figure 3) in Egypt (Fazaeli, 2004: 71). Hasour was a goddess in the sky. Therefore, Nut, the goddess of sky is his mother and Ra, is his father. Worship of Hasour, the female goddess, the cow, was common in Egypt from the ancient times, and in the sky it was in the form of a cow or Taurus, and was called Lady of the stars and the lady of the sky (Javan, 2007: 277).

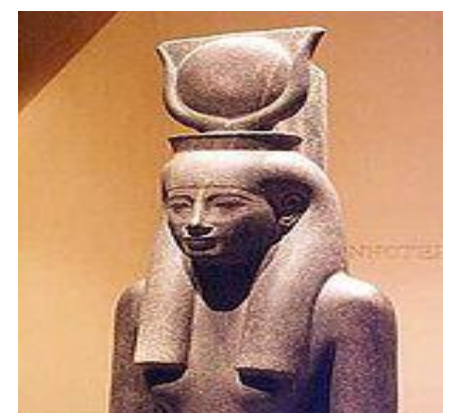

Figure 3. Image of Hasour - Egyptian God - her head in the form of a cow (Javaheri, 2011: 105)

The significance of the goddess Nut in that era was such that as described in two Egyptian inscriptions, after the conquest of Egypt, the Achaemenid kings, Cambyses and Dariush the Great called themselves the son of the Nut, the mother of Egyptian gods, and the son of Horus the great Egyptian God (ibid, 270). Plutarch, the famous Greek historian of the second century AD, compared her Athena, and referred to the worship of her. According to L. Chaumont, a German writer, this goddess is an obvious reference to Anahita. She notes that the history of this defensive character of this goddess, who later Sassanids gave her the head of their failed enemies, goes back to the first century AD. Thanks to Herodotus, who says that Xerxes sacrificed for Athena (i.e. Anahita) before wars, so we can bring it back to earlier times (Yarshater, v. 3/2, p. 301). In ancient Greece, Athena was sometimes called the goddess of wisdom, sometimes the goddess of war, and sometimes the goddess of knitting. In Egypt, on the other hand, Nith or Anaitis was also the goddess of War, and the skilled woman in knitting, who in the seventh century BC was the protector and guardian of the people in Sais, the capital of Egypt (Rezapur,2005:211). 


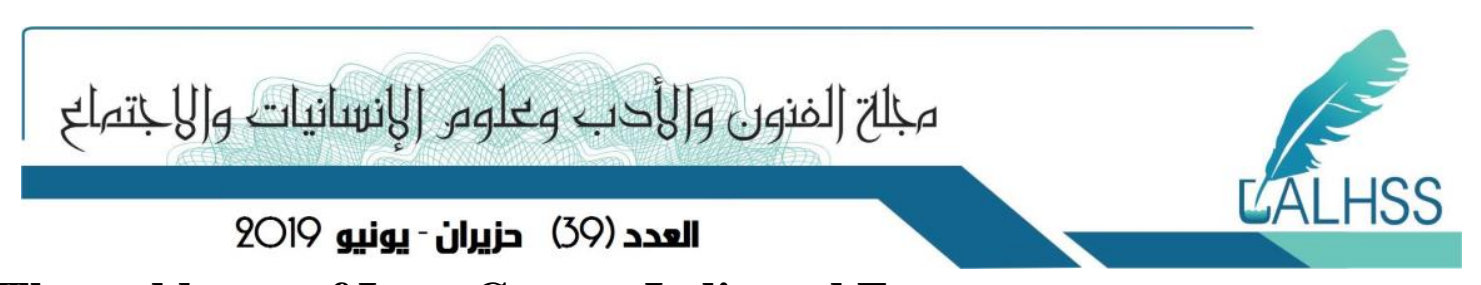

\section{The goddesses of Iran, Greece, India and Egypt}

Haurvatat (Health) and Amertat are other Iranian goddesses that can be adapted to Asvin or Indian Nasatias. Haurvatat was the god of sun, while Amertat was reigning over the herbs. In India, Utat and Sarvatat are the peers of Amertat and Haurvatat, respectively (Widengren, 1998: 40). One of the other Iranian gods, similar to those in India and Greece, was Sepandarmaz or Spantana Armaiti. This goddess was equal to Dionysus, the god of fertility in Greece, and it was mentioned as Sandaramet in Armenia (Rajabi, 2001: 391). On the other hand, it can be similar to the first goddess of fertility, Gaia (Rosenberg, 1999: 70). According to the Zoroastrian and Vedic sources, there is no doubt that the Armaiti has an Indo-Iranian history and it is clear that Zoroaster, the creator of religion in eastern Iran, has used hereditary materials; A memory that remains, though weak, as Aramati in India. Before Zoroaster, the god of the sky and the god of the earth were holy for the Iranians and it is clear that the concepts of father of the sky and mother of the earth have remained from the earliest times for the Persians and Indians (Boyce, 1995: v. 1: 78). In such a way that the great goddess of the earth, Paritvi Matar is admired in Rigveda (Coomaraswamy, 2003: 135). Some scholars mentioned that Sepandarmaz, like the other Ameshaspands is originated from the ancient Indo-Iranian gods (Warner, 2007: 254). The Sepandarmaz in the Avesta and the Pahlavi texts sometimes refers to earth and is used as its synonym (Bundahishn, 2001: 81). In addition, in the mythology of ancient Iran, Sepandaramz, is the symbol of tolerance, the guardian angel of the earth, and the fertilizing and purifying it, and the joy and comfort of the earth has been given to her kind hands. Zoroastrians, while drinking Haoma, donate some of it to the earth for the satisfaction of this goddess (Anasori, 1982: 806).

Another Iranian goddess, whose peer can be found in Greece and India, is the goddess Čista who is described as the white. This goddess was the guardian of science in Ancient Iran (Zarshenas,2006). In Greek mythology, the two gods that are the foundation of wisdom and knowledge are Metis and Athena, which lie under the power of the Zeus, the gods of gods (Smith, 2010: 7). Metis was the wife of Zeus, and when she was pregnant with Athena, Zeus, accepting the other gods' statements swallowed her to protect his godly power from the power of wisdom of this unborn child. After this, Athena was born from the forehead of Zeus and became the symbol of the wisdom of the gods (Sanjari., 2016: 110). It can also be compared with the Virgin, the goddess resembling wisdom, reason and sincerity (Sanepour, 2014: 49). Goddess Čista in India is somehow comparable to the great goddess Devi or Jai Mata Di, the most powerful goddess.

The trait of this goddess is a mixture of pre-Aryan mother-god and wife of Shiva. In the recent role, she is the perfect reflection of her husband (Veronica, 1994: 162). On the other hand, in this land, Vāc or the goddess of speech and the words is compared to goddess Čista, which is said that the Sanskrit language is her innovation (ibid. 158). The goddess Daena in ancient Iran was among other goddesses, which has a peer in ancient India. This goddess is the symbol of conscience (Amoozegar, 2007:31) and is the goddess of religion. The word Dahi in Sanskrit is equal to this goddess (Avesta, 2006:144). The roles of each of the goddesses differed according to the regions and cultures where they were worshiped. 


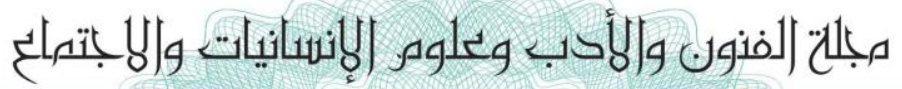

\section{العدد (39) حزيران - يونيو 2019}

Basically, she was the mother, the birth giver and the source of the new life. So she was connected with the cycle of agriculture and wildlife, too. She was also the wife of male gods and occasionally the god of the sky, and sometimes his wife or his son, and she endured the death and resurrection, which symbolized the resurgence of nature in the spring, such as Ishtar and Dumuzid in Mesopotamia and Isis and Osiris in Egypt. Sometimes this goddess as a hunter has a special bond with animals, as in this case, is the Greek goddess of Artemis, who in one of her roles supported wild animlas (Jalali Moqaddam, 2008: 107). Ashi, the goddess of wealth, interest and forgiveness, whom the sentennth Yasht of Avesta is assigned to (Yashts, 1977: 468), is another goddess that sometimes means wealth, forgiveness, blessing, and sometimes is a name for the god who is guardian of wealth and the property of the people on the earth (Ahi, 1967: 45). This goddess is somehow similar to the Parandi goddess, and on the other hand, with regard to her role and importance in wealth and property, she can be compared with the goddess of wealth and blessing in India, Lakshmi (Figure 4). (Pourdavoud, 1998: 180).

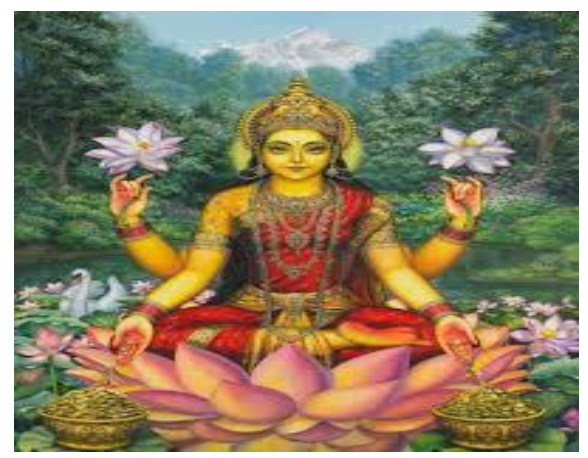

Figure 4. Lakshmi in India (Ferghadan, 2010: 53)

Lakshmi is often drawn on a lily among the elephants while golden coins are raining from her hands (Shattuck, 2002: 66). Lakshmi is the goddess of happiness, embodiment of love, beauty, fertility and wealth in India. Her portraits in Hindu art are among the lilies, with a red garment, decorated with jewelry and adornment, often giving money or other blessings to the worshipers (Hinnells, 2007: 558). Of course, Georges Dumezil, a French mythologist and Geo Widengren, a Swedish linguist and Iran expert, have compared Asha with Indian Bhaga, saying that this goddess means gain and interest (Widengren, 1998: 34), and it means to take advantage of the good things and the blessings of the world (Boyce, 1997: 76), and in Rigveda sometimes it is used as property and fortune, sometimes in the sense of divider, and sometimes it means gracious (Shayegan, 2004: 76).

\section{Egyptian and Greek goddesses with the same functions}

Religion in Egypt reflects a complex, unchanging world image. If a new god or goddess appeared, or a new religion or belief was established, they would not replace the existing 


$$
\text { مجلة" الفنون والأذب وعلوه الإنسانيات والهبتهرأغ }
$$

\section{العدد (39) حزيران - يونيو 2019}

gods or goddesses or beliefs, but gods and goddesses were only ascended or descended in terms of popularity. In fact, new beliefs were added to old beliefs and nothing were left aside. In Egypt, most of the goddesses were portrayed partly as animals and partly as mankind. Of course, some historians believe that the Egyptians depicted the goddesses of animals in order to enable people to distinguish between different goddesses; for an illiterate population, this was an easy way to distinguish a goddess from the other goddesses (Lassieur, 2008: 54).

The Greeks, at least since Herodotus, were aware of the existence of the Egyptian gods, especially the Egyptian goddess Isis. Believing that, the worship of Isis and her husband, Osiris, in Egypt, is similar to their secret rituals. But the first signs of the similarity of the Greek secret rituals with the goddess Isis were mentioned in a virtue that was carved on a plane and displayed in the temples of Isis in the last two centuries BC. Isis declares that he has given agriculture, some useful rules and benefits to humanity and has taught humans how to hold the rituals of entering to secrets. Here, Isis is unified with the Greek goddess Demeter $^{1}$ (Iles Johnston, 2014: 146-147). As the goddess of love she is compared with Aphrodite, as the wife of the King of the Gods is compared with Hera, and as the goddess of magical arts is compared with Hecate; on the other hand, she can be compared with Eros the God Love in the Greek mythology (Warner, 2007: 175). This goddess in Mesopotamia is similar to the Tiamat, which was the root of all life (Cope, 2011: 1-2). The goddess of Mat (Figure 5) was one of the Egyptian goddesses, and was the female god of order and righteousness. It is seen in her wall images that she is taking a feather from an ostrich. This God is the personality of truth, righteousness, and order. So that she puts the ostrich feather on a scale in the other world to measure the dead soul fairly in the presence of the King, Osiris, because her feather on the scale is the benchmark of fairness and impartiality in determining the fate (Gootterell, 1991: pp. 11-34).

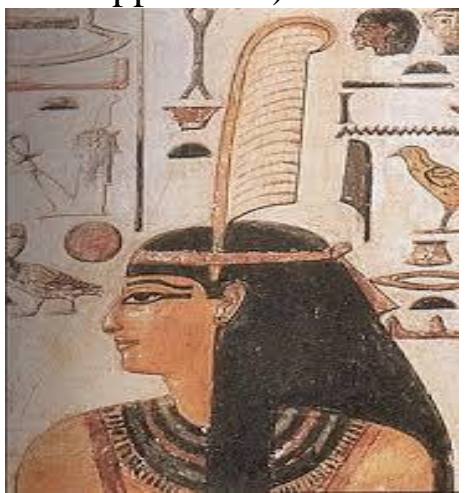

Figure 5. Mat Goddess of truth and righteousness in ancient Egypt

(Javaheri, 2011: 104)

\footnotetext{
${ }^{1}$ Meter (mother) is the name of the goddesses who were either natives of Greece, or entered from Anatolia. Their worship included an ecstasy dance that reduced feelings of pain; and at the peak of this state, some men castrated themselves, thus giving their own sexual power to the goddess and thereafter became eunuch priests of the goddess.
} 


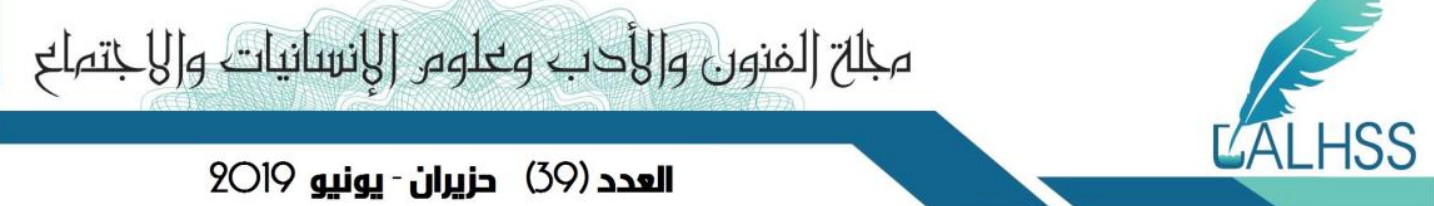

The other worshiped goddess in ancient Egypt was Nut; a goddess who embraces the earth while she is bent. In this land, she is the mother of the gods, and the Greeks consider her as the mother of the Greek gods, Rea (Vieu, 1996: 23).

One of the gods worshiped in all religions was fire, which was addressed in various territories with different names. In some countries, this god is male, and in the others it is female, as in Iran, was called Atar, the son of Ahuramazda. But in Egypt and Greece it has been depicted as a goddess. In ancient Greece, the goddess of fire was called Hestia, and the immortal fire was kept at the temple of Hestia (Afifi, 2004: 407). This goddess was worshiped in Egypt under the name of Sekhat, that has a female lion head. Egyptians like other nations, including Iran, India and Greece, believing in the purity and cleansing of fire, it was linked to their belief in resurrection (Bakhourtash, 1991: 88).

\section{Conclusion}

The goddesses from the ancient times of human history, from the Paleolithic and Neolithic period, have been important and significant, and were seen in the myths of various tribes, especially Elam, Mesopotamia, Iran, Greece and Egypt. The distinguishing feature of the motherhood of a woman, and in particular her protection of the family, made the woman a spiritual personality with divine status, and caused her to be worshiped as a goddess in ancient civilizations, and her images were displayed in various paintings. Some statues of these goddesses are obtained. It should be said that the significance of these goddesses were depended on the geographical situation in which they were located. So that each of these goddesses had their own specific qualities and roles, such as blessing, reproduction or fertility, the symbol of water and life, earth, sky, beauty and magic, etc. The significance of these goddesses in ancient Elam was such that many historians believed in the matriarchy period in Elam. The goddesses of Elam were in some way in harmony with the goddesses of Mesopotamia, who had the most cultural and religious contacts with, and they were largely originated from that land, and by examining the religious themes of these two civilizations, one can find an example in the other civilization. The reflection of the worship of the mother-goddess gradually reached to Iran, Greece, and Egypt civilizations, where similar goddesses were worshiped, too. The goddesses who had their own special roles, and their importance and function were changed according to the time.

\section{References}

1- Afifi, R. (2004). Mythology and Culture of Iran. Tehran: Toos.

2- Ahi, H. et al. (1967). Woman in Ancient Iran. Tehran: Women's Academic Press.

3- Amouzegar, J. (2007). Mythological History of Iran. Tehran: Samt.

4- Anasori, J. (1981). “ Dordanehaye Khalvate Khiyal”.The Goddess "Anahita” The Goddess of water and the Queen of the Rivers; "Faghfor" Azar, Warmer of the Souls and the Guardian of Fire", Chista. Vol.2, No. 14, 410-436.

5- Jalil, D. (2000). Avesta. Tehran: Morvarid.

6- Bahar, M. (2005). Asian Religions. Tehran: Cheshmeh.

7- Bahar, M. (2007). A Research in Iranian Mythology. Tehran: Agah. 
8- Bakhtourtash, N. (2008). The Mysterious Insignia of the Sun or Mehr's Carrousel. Tehran: Artemis.

9- Feranbagh Dadagi. (2001). Bondahishn. Tehran: Toos.

10- Boyce, M. (1995). The History of Zoroastrianism, translated by Homayoun Sanatiadeh. Tehran: Toos.

11- Boyce, M. (2002). Zoroastrians, Their Religious Beliefs and Customs, translated by Askar Bahrami. Tehran: Qoqnous.

12- Cameron. G. (1936). History of Early Iran. Chicago: University of Chicago Press.

13- Christensen, A. (1953). Iran during the Sassanid Era. translated by Yasemi, R. Tehran: Avicenna.

14- Cope, L. (2011). Myth, Translated by Dehqani ,M. Tehran: Scientific and Cultural.

15- Coomaraswamy, A. (2003). Introduction to Indian Art, translated by Zekergo, A. Tehran: Rozaneh.

16- Cooper, J.C. (1968). Illustrated Encyclopedia of Traditional Symbols. London.

17- Edwards, E.P.S. (2012). History of the ancient world of Elam - Northern Mesopotamia and Syria, translated by Qaderi, T. Tehran: Mahtab.

18- Eliade, M. (1997). A Thesis in the History of Religions, translated by Sattari, J. Tehran: Soroush.

19- Eskandari, Sh. (2001). Mythological Concepts of Goddesses in the Civilizations of Ancient East, Egypt, India, Mesopotamia, Elam. Tehran: Al-Zahra University.

20- Esmailpour, A. (2008). Myth, the Symbolic Expression. Tehran: Soroush.

21- Fanian, Kh. (1972). "Worship of the Mother-Goddess in Iran", Journal of Historical Surveys, Vol.6, No. 6, 209-248.

22- Fazaeli, S. (2004). Ghareb Lexicon. Tehran: Cultural Heritage Organization.

23- Ferghdan.A, Hoshyar.M. (2010). "Comparative Study of Water Lily in Iran, India and Egypt". Illustrative Art Journal Quarterly.Vol.3, No.6, 49-58.

24- Gaviri, S. (2000). Anahita in Iranian Mythology. Tehran: Jamal al-Haq.

25- Getty, A. (1990). Goddess Mother of Living Nature. London: Thames and Hudson LTD.

26- Gholamali, A. (2003). Introduction to the History of Religions. Tehran: Paya.

27- Giovinazzo, G.(___ Elam Religion, Comprehensive History of Iran, translated by Ashkar Bahrami. Great Islamic Encyclopedia.

28- Gotteral, A. (1991). word mythology. Oxford.

29- Hinnells, J. (1994). Recognition of Iranian Mythology, translated by Amouzagar, J; and Tafazolli, A. Tehran: Cheshmeh.

30- Hinz, W. (1997). the Lost World of Elam, translated by Firouznia, F. Tehran: Institute for Cultural Studies and Research.

31- Iles Johnston, S. (2015). An Introduction to the Religions of the Ancient World. translated by Firouzi. Tehran: Qoqnous.

32- Jalali Moqaddam, M. (2008). Overview of World Religions. Tehran: Sokhan.

33- Javaheri, B. (2011). "Role of Women in Pharaohs Civilization with the Emphasis on Archeological discoveries in Recent Empire Period", Women in Culture and Art Journal, Vol.3, No.2, 97-116.

34- Javan, M. (2007). Social History of Ancient Iran. Tehran: Oloum.

35- Kitto, D. H.(2014). Greeks, translated by Aqeli, S. Tehran: Mahi.

36- Lassieur, A. (2008). Ancient Egyptians, translated by Mirsaidi, N. Tehran, Qoqnous.

37- Malandra, W.W. (1983). An Instruction to Ancient Iranian Religion. Minneapolis. 
38- Majidzadeh.Y. (2000). History of Mesopotamia. Tehran, Vol.2, Center of Academic Publication.

39- Noss, D. (1994). History of the World's Religions. Heidelberg.

40- Pashtunizadeh. A. (2017), "Role of Anahita in Artistic Artifacts", Women in Culture and Art, Vol.9, No.1, 93-117.

41- Pourdavood, E. (1977). Yashts, vol. I and II, by the efforts of Bahram Farah Vashi. Tehran: Institute of and Printing of Tehran University.

42- Rajabi, P. (2001). Missing Millenniums. Vol. I. Tehran: Toos.

43- Rezapur, M. (2005). "The Linkage of the Mythical and Epic Goddesss' Functions in Ancient Stories", Journal of Persian Language and Literature, Language and Literature Faculty, Allameh Tabatabai University, No. 25, 207-218.

44- Rosenberg, D. (1999). Mythology of the World; Stories and Epics, translated by Sharifian, A. Tehran: Asatir.

45- Samadi, M. (1988). Moon in Iran from the Earliest Days to the Advent of Islam. Tehran: Scientific and Cultural.

46- Sanepour, M. (2014). "The Democracy of Ancient Greek Myths and Its Impact on the Enlightenment of Europe", Women's Research, Human Sciences and Cultural Research Institute, Vol. 5, No. 2, 47-58.

47- Sanjari, S. (2016). "Cultural Analysis of Ancient Texts on the Choice of Women's Names", Journal of Women and Culture, Vol.7, No. 27, 103-119.

48- Sarraf, M. (2005). Religion of the people of Ilam. Tehran: Samt.

49- Shattuck, C. (2002). Hinduism, translated by Hasan Afshar. Tehran: Markaz.

50- Shayegan, D. (2004). Religions and Philosophical Schools of India. vol. 1. Tehran: Amir Kabir.

51- Smith, J. (2010). Iranian and Roman Mythology Culture, translated by Baradaran Khosroshahi, Sh. Tehran: Contemporary Culture and Roozbehan.

52- Taheri.S. (2007), "Fertility goddesses in Ancient Era", Modarese Honar Quarterly. Vol.2, No.2, 41-56.

53- Veronica, I. (1994). Mythology of India, translated by Farrokhi Bajlan, Tehran: Asatir.

54- Vieu, J. (1996). The Culture of Egyptian Mythology, translated by Esmailpour, A. Tehran: Fekre rooz.

55- Warner, R. (2007). The Encyclopedia of World Mythology, translated by Esmailpour, A. Tehran: Ostoure.

56- Widengren, G. (1998). Iranian Religions, translated by Farhang M. Tehran, Agahan Dide.

57- Yarshater, E. (1999). "The Evolution of Religious Thought", Iran-Cambridge History from the Seleucid Empire to the collapse of the Sassanid Empire, translated by Anousheh, H. Tehran: Amir Kabir.

58- Zarshenas, Z. (2006). Women and Word, Collector Dr. Vida Naddaf, Tehran: Farvahar. 